\title{
PEANUT AS A CAUSE OF TORSION MECKEL'S DIVERTICULUM
}

\author{
Sekulic Stojan, ${ }^{1}$ Sekulic-Frkovic Aleksandra, ${ }^{2}$ Milankov Andrijana ${ }^{3}$ \\ ${ }^{1}$ Surgical Clinic, C.H.C, Pristina - Gracanica, University of Pristina, Faculty of Medicine, \\ Kosovska Mitrovica, Gracanica, Serbia \\ ${ }^{2}$ Pediatric Clinic, C.H.C, Pristina - Gracanica, University of Pristina, Faculty of Medicine, \\ Kosovska Mitrovica, Gracanica, Serbia \\ ${ }^{3}$ Endocrinology Clinic, Clinical Centre of Vojvodine, Faculty of medicine Novi Sad, Serbia
}

Primljen/Received 17. 05. 2015. god.

Abstract: Introduction: Meckel's diverticulum is a congenital anomaly of the small intestine and remnant of omphalomesenteric duct. It can be found in about $2 \%$ of the population. The diagnosis of Meckel's diverticulum is mostly established during surgical intervention.

Case report: Our research is based on the 22 years old female patient, who has been admitted to the clinic with all the features of acute appendicitis. After the completion of 20 hours of observation, intestinal permanence - ileus, was diagnosed. The patient was operated after a brief reanimation and anesthetic preparation. $\mathrm{Du}-$ ring the surgical intervention, we have found a normal appendix, without signs of inflammation. Further exploration of the abdomen fortified Meckel's diverticulum at a distance of $75 \mathrm{~cm}$ from the ileocecal valve of the ileum. Diverticulum was completely filled in with peanuts, and wreathed around its axis, causing the ileus. We have performed diverticulectomy and appendectomy. The patient had a rapid and successful postoperative course.

Conclusion: Apart from the acute appendicitis, when patient complains on pains in ileocecal region, Meckel's diverticulum should also be taken into a consideration.

Key words: Meckel's, diverticulum, ileus, torsion.

\section{INTRODUCTION}

Meckel's diverticulum is congenital anomaly of the gastrointestinal tract. It is a backlog of unclosed omphalomesenteric duct that usually closes in the seventh week of gestation. It occurs in about $2 \%$ of the population and it is located on the antimesenteric side of ileum, $50-90 \mathrm{~cm}$ of Buchini's valve $(1,2,3)$. For the Meckel's diverticulum usually applies rule of twos: extends 2 inches $(5 \mathrm{~cm})$ in length, it is 2 feet $(70 \mathrm{~cm})$ distant from the ileocecal valve, occurs in $2 \%$ of the population, most commonly is manifested in the first 2 years
Prihvaćen/Accepted 23. 06. 2015. god.

of life and it can contain 2 types of epithelial tissue. Diagnosis of diverticulosis is not simple to establish $(4,5)$. It is usually manifested with clinical signs of inflammation of the appendix and diagnosed during surgery and therefore it is necessary for each appendectomy to make exploration of the ileum, $90 \mathrm{~cm}$ from the ileocecal valve. It can be manifested as gastrointestinal bleeding, or invagination ileus due to torsion. X-ray, US and CT play an important role in diagnosis of Meckel's diverticulum. It is treated surgically: diverticulectomy, wedge resection and resection of the ileum. If there are no complications (gangrene, perforation) postoperative course is fast and completes without complications. The most common complications are bleeding without pain, ileus (invagination or torsion) and perforation. The risk of occurrence of these complications is in $4-6 \%$ of people with Meckel's diverticulum $(5,6,7,8)$.

\section{CASE REPORT}

At the Surgical Clinic, Hospital Centre in Pristina - Gracanica, 22 years old female patient was admitted with abdominal pain for observation. The pain had started 12 hours before admission in the right lower quadrant of the abdomen. Pains were becoming more intensive and followed with nausea and vomiting. Anamnesis did not contain any significant data that would indicate disease. Patient was not sick nor had any surgical intervention. There were not big changes in nutrition, except the consumption of larger amount of peanuts, about 24 hours after the onset of symptoms. No diarrhea. We have detected palpatory soft abdomen with enhanced sensitivity in the ileocecal region on deep palpation. There was no difference in the axial and the rectal temperature of $1^{\circ} \mathrm{C}$. Laboratory: $\mathrm{Le}-9.2 \times 10 \mathrm{~g} / \mathrm{l}$, neutrophils normal, $\mathrm{Er}-4,9$ $\mathrm{x} 1012, \mathrm{Hb}-119 \mathrm{~g} / \mathrm{l}$, urine results in the normal range. 
The clinical picture varied from hour to hour. Pain was increasing, such as distension of the abdomen and increasing urge to vomit. Native abdominal $\mathrm{x}$-ray was done and showed hydraulic shadows in the right part of the abdomen. It led to an indication of appendix inflammation - of the acute abdomen and required surgical intervention. Short and quick resuscitation was made, such as anesthetic preparation of the patient.

With the right McBarney's cut the abdominal cavity was opened. Luxating the cecum we have not found any signs of the appendix inflammation. Appendectomy was performed. The incision was expanded for exploration of the abdominal cavity. In the abdominal cavity was not any other content. Exploration of the abdominal cavity ascertaind the flank mass. At $75 \mathrm{~cm}$ from the ileocecal valve the Meckel's diverticulum was verified, with a length of about $5 \mathrm{~cm}$ and $2 \mathrm{~cm}$ wide, and with torsion around the ileum that made obstruction of the ileum. Detorqution was done, the wall of the ileum was not changed, the diverticulum was opened and found completely filled in with peanuts. After diverticulum was emptied, diverticulectomy and suture of ileum 3.0 PDS was done with thread (Figure 1, 2, 3). Operative wound was closed in layers. The postoperative course was normal. Intestinal

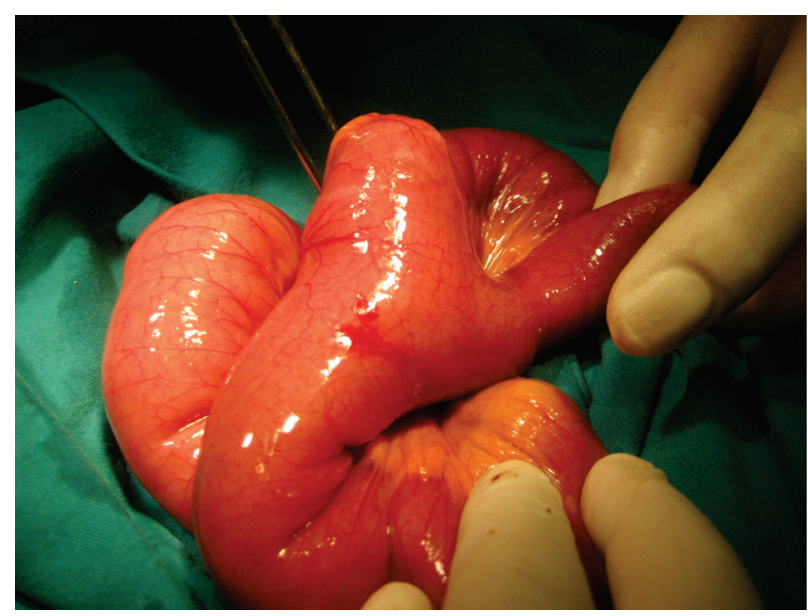

Figure 1. Meckel's diverticulum - detorquation

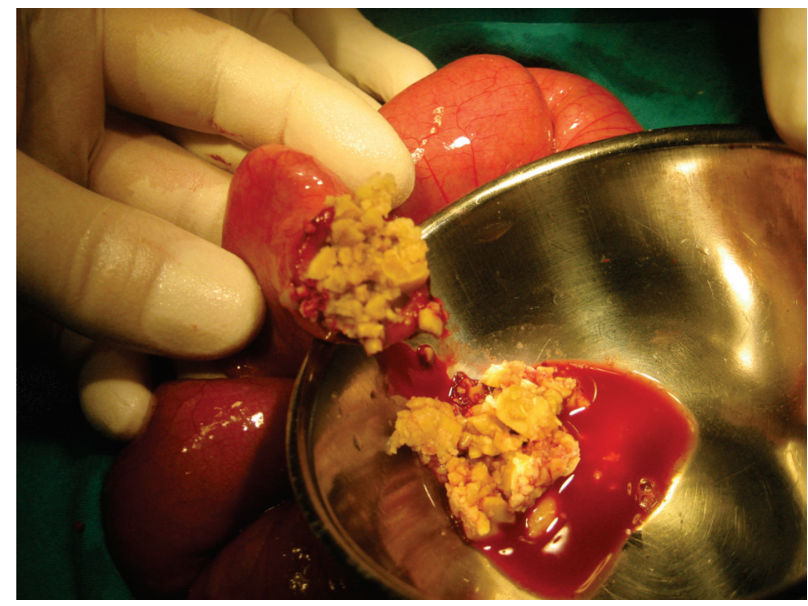

Figure 2. Meckel's diverticulum filled with peanuts

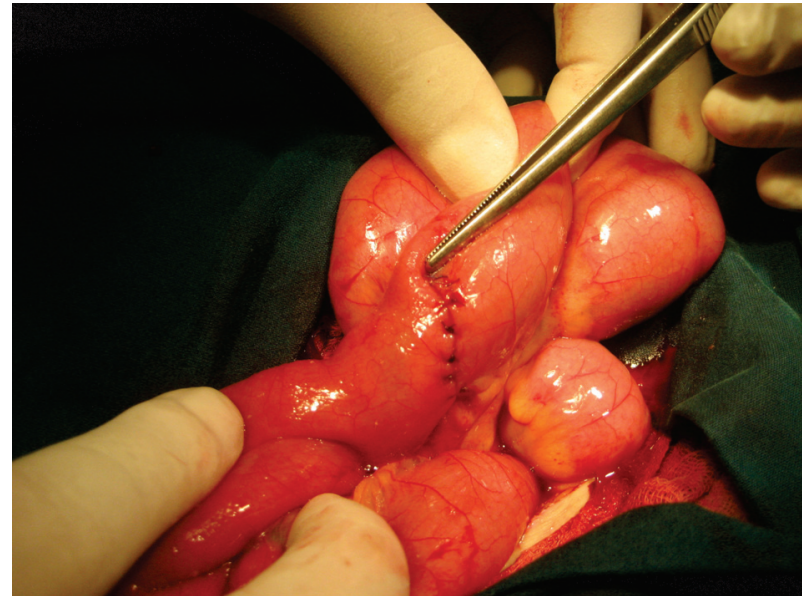

Figure 3. Surgical treatment/diverticulectomy

peristalsis was established 36 hours after surgical intervention. On the third postoperative day patient started with taking liquids, then pureed foods. The patient was released from hospital on the fifth postoperative day in good general condition. Laboratory parameters were within normal limits. Operative wound healed primarily, and stitches were removed on the eighth postoperative day.

\section{DISCUSSION}

Diagnostics and treatment of the Meckel's diverticulum remain controversial and the subject of many debates. Generally, when a Meckel's diverticulum is diagnosed by chance by some diagnostic method, surgical intervention is not required $(4,5)$. But, if it is found in younger patients, without complications-accidentally or with complications, it needs to be surgically removed. The risk of death in the case of Meckel's diverticulum is $0.001 \%$, but with complications (bleeding, perforation or obstruction) can reach 4-6\% $(6,7,8)$. For these reasons, many surgeons believe that it is necessary to surgically treat diverticulum at incidental findings, while some studies suggest that it does not need to be touched in case of the elderly people if it has a wide lumen (9-17). We believe that it is necessary to surgically treat Meckel's diverticulum always in order to prevent any complications.

In our case, Meckel's diverticulum was filled in with peanuts that caused twisting of ileum and obstruction. There were no major changes or gangrene of the ileum, due to rapid surgical intervention, so we did just diverticulectomy and suture with 3.0 PDS thread. Because of the "on time" surgical intervention we have avoided the complications.

\section{CONCLUSION}

Diverticulum Meckeli is mainly manifested with the clinical picture of inflammation of the appendix, or the complications. It needs to be surgically treated when the diagnosis is set. 


\title{
Sažetak
}

\section{KIKIRIKI KAO UZROK UVRTANJA MECKEL-OVOG DIVERTIKULUMA}

\author{
Sekulic Stojan, ${ }^{1}$ Sekulic-Frkovic Aleksandra, ${ }^{2}$ Milankov Andrijana ${ }^{3}$
}

\footnotetext{
${ }^{1}$ Hirurška klinika KBC Priština — Gračanica, Univerzitet u Prištini, Medicinski fakultet Kosovska Mitrovica, Gračanica, Srbija

${ }^{2}$ Pedijatrijska klinika, KBC Priština — Gračanica, Univerzitet u Prištini, Medicinski fakultet Kosovska Mitrovica, Gračanica, Srbija

${ }^{3}$ Klinika za endokrinologiju, Klinički centar Vojvodine, Medicinski fakultet Novi Sad, Srbija
}

Uvod: Meckel-ov divertikulum je ostatak omfaloenteričnog kanala. To je urođena anomalija tankog creva. Sreće se u oko $2 \%$ populacije. Dijagnoza Meckel-ovog divertikulum se uglavnom postavlja slučajno prilikom hirurške intervencije.

Prikaz slučaja: Devojka stara 22 godine, primljena na Kliniku pod kliničkom slikom akutnog zapaljenja crvuljka. Posle 20 sati posmatranja postavlja se dijagnoza crevne neprolaznosti — ileusa. Posle kratke reanimacije i anesteziološke pripreme pacijent je ope-

\section{REFERENCES}

1. Srinivas G. N, Cullen P. Intestinal obstruction due to Meckel's diverticulum: A rare presentation. Acta Chir. Belg. 2007; 107(1): 64-6.

2. Williams RS. Managament of Meckel's diverticulum. Br J Surg. 1981; 68(7): 477-80.

3. Spottswood SE, Pfluger T, Bartold SP, et al. SNMMI and EANM practice guideline for meckel diverticulum scintigraphy 2.0. J Nucl Med Technol. 2014; 42(3): 163-9.

4. DiGiacomo JC, Cottone FJ. Surgical treatment of Meckel's diverticulum. South Med J. 1993; 86(6): 671-5.

5. Cullen JJ, Kelly KA, Moir CR, Hodge DO, Zinsmeister $\mathrm{AR}$, Melton Lj 3rd. Surgical management of Meckel's diverticulum. An epidemiologic, population-based study. Ann Surg 1994; 220(4): 564-9.

6. Artigas V, Calabuig R, Badia F, Rius X, Allende L, Jover J. Meckel's diverticulum: value of ectopic tissue. Am J Surg. 1986; 151(5): 631-4.

7. Mackey WC, Dineen P. A fifty-year experience with Meckel's diverticulum. Surg Gynecol Obst. 1983; 156(1): 56-64.

8. Shinohara M, Mori M, Mimuro A, at all. A Case of Perforated Meckel's Diverticulum in the Elderly - A Review of 119 Cases. Journal of Japanese College of Surgeons. 2004; 29(6): 1002-6.

9. McKay R. High incidence of symptomatic Meckel's diverticulum in patients less than fifty years of age: an indication for resection. Am Surg. 2007; 73(3): 271-5.

\section{Correspondence to/Autor za korespondenciju}

Prof. dr Stojan Sekulic MD, PhD

St. Danila Kisa 36/43

21000 Novi Sad

Serbia

E-mail: stojan.sekulic54@gmail.com

Tel: +381645105490 risan. Operativno je nađen normalan crvuljak. Eksploracijom trbušne duplje utvrđen je Meckel-ov divertikulum na udaljenosti od $75 \mathrm{~cm}$ od ileocekalnog ušća na ileumu. Divertikulum je bio u potpunosti ispunjen kikirikijem, i uvrnut oko svoje osovine što je izazvalo ileus. Urađena je divertikulektomija i apendektomija. Bolesnica je imala brz i uspešan postoperativni tok.

Zaključak: Kod bola u ileocekalnoj regiji osim zapaljenja crvuljka treba misliti i na Meckel-ov divertikulum.

Ključne reči: Meckel, divertikulum, ileus, uvrtanje.

10. Dumper J, Mackenzie S, Mitchell P, Sutheriand F, Quan ML, Mew D. Complications of Meckel's diverticula in adults. Can J Surg. 2006; 49(5): 353-7.

11. Thirunavukarasu P, Sathaiah M, Sukumar S et al. Meckel's diverticulum - a high-risk region for malignancy in the ileum. Insights from a population-based epidemiological study and implications in surgical management. Ann Surg. 2011; 253 (2): 223-30.

12. Mohiuddin SS, Gonzalez A, Corpron C. Meckel's diverticulum with small bowel obstruction presenting as appendicitis in a pediatric patent. JSLS. 2011; 15(4): 558-61.

13. Caillouet IS, Jaffe BM. Torsion and gangrene of a Meckel's divertikulum. J La State Med Soc. 2009; 161(1): 19-22.

14. Kivak G, Ergul E, Sarikaya SM, Kusdemir A. Axial torsion and gangrene of a giant Meckel's diverticulum mimicking acute appendicitis. J Pak Med Assoc. 2009; 59(6): 408-9.

15. Tauro LF, George C, Rao BS, Martis JJ, Menezes LT, Shenoy HD. Asymptomatic Meckel's diverticulum in adults: is diverticulectomy indicated? Saudi J Gastroenterol. 2010; 16(3): 198-202.

16. Alemayehu H, Stringel G, Lo IJ, et al. Laparoscopy and complicated meckel diverticulum in children. JSLS. 2014; 18(3): e2014.00015.

17. Ruscher KA, Fisher JN, Hughes CD, et al. National trends in the surgical management of Meckel's diverticulum. J Pediatr Surg. 2011; 46(5): 893-6. 